\title{
A New Indian Academy of Sciences
}

$\mathrm{I}^{\mathrm{N}}$ the fog of political turmoil in which India has for so long been enshrouded, the remarkable scientific developments which have taken place in recent years have been somewhat overlooked. To those acquainted with the conditions prevailing at the beginning of the century, when scientific research was confined almost solely to the specialist Government departments, such as the Survey of India or the Geological Survey, and to the two veterans, who are still happily with us, Sir J. C. Bose and Sir P. C. Rây, the present conditions must appear remarkable.

The scientific renaissance of India dates from the reorganisation of the universities about twenty years ago following on the report of the Curzon Commission. Prior to this the university colleges were little more than high schools, and even so late as 1910 it was possible to take a degree in physics without undergoing any laboratory instruction. With the introduction of honours courses and the consequential increase of staff, the value of scientific research was gradually recognised, so that at the present time the output of original work from the Indian universities compares not unfavourably with that of the West. An outcome of this development has been the formation of new specialist societies which may all be regarded as the offspring of the Indian analogue of the Royal Society, the Asiatic Society of Bengal, which celebrated its centenary in 1913. This old society, full of vitality as it still is, has the disadvantage that its influence is confined practically to Calcutta and its environs. In 1914 the Indian Science Congress was founded, a peripatetic body modelled on the lines of the British Association. This body met with immediate success as is testified by the large attendance at its meetings and the large number of scientific communications read before it. The Indian Science Congress does not, however, undertake the publication of these communications except in abstract, and a natural nationalist spirit, coupled with the long delay associated with publication in European and American journals, has resulted in the foundation of the Indian Chemical Society and of the Indian Journal of Physics.

The most recent development is the formation of the Academy of Sciences of the United Provinces, with its seat at Allahabad. A movement for the creation of an Academy was started by Prof. M. N. Saha in 1929, and advantage was taken of the meeting of the Indian Science Congress in 1930 in Allahabad to discuss the functions of the proposed Academy. As a result of the interest and sympathy shown it was registered in December of that year. The first volume of its Bulletin has now been published, and this contains an account of the inaugural meeting held on March 1 . The main objects of the Academy, of which Prof. Saha is the first president, are the encouragement of science in its various branches, more especially in the United Provinces, and the publication of the results of scientific research, either in its Bulletin or in the form of Transactions and Memoirs. The membership of the Academy, as in the case of the Asiatic Society of Bengal, is divided into two classes, fellows elected for their scientific eminence, the number being limited to thirty, and ordinary members of whom no special qualifications are required. The successful inauguration of this body is welcome evidence of the increasing value now attached to scientific research in India, but it seems somewhat questionable if the publication of a new journal is desirable.

The first Bulletin contains twenty-seven original memoirs and it is divided into the following heads :-mathematics, physics, chemistry, industrial chemistry, zoology, botany and general. Under the last heading there is an interesting paper by Sir C. V. Raman on "Spin of Light". Many of the communications could with equal advantage have appeared in the Indian Journal of Physics or in the Journal of the Indian Chemical Society, and it seems likely that some of them will be published in extenso elsewhere, since they are only short abstracts and are so headed. Time will show if there is a real need for the Bulletin, but with so distinguished and energetic a president and with such admirable secretaries as Prof. P. S. MacMahon and Prof. A. C. Banerji, the future success of the Academy seems assured, and there is little doubt that it will do much to stimulate the research spirit in the Universities of Allahabad, Lucknow, Aligarh and Benares.

\section{The Colloid Aspects of Textile Materials}

$\mathrm{E}$ IGHT years ago, the Faraday Society made an interesting experiment in devoting one of its discussions to "Physical and Physico-Chemical Problems Relating to Textile Fibres". At that time the study of fibres was in its infancy, with an uncertain future, and all workers in the subject owe the Society a debt of gratitude for early encouragement during difficult years. Courageous patronage deserves a rich reward, and this the Society achieved in the outstanding success of the second discussion on "The Colloid Aspects of Textile Materials", which was held in the Chemistry Department of the University of Manchester on Sept. 21-23. The meeting was noteworthy for the number and distinction of its overseas visitors and contributors, among whom were included E. H. Büchner (Amsterdam), E. Elöd (Karlsruhe), R. O. Herzog (Berlin), G. van Iterson (Delft), J. R. Katz (Amsterdam), P. Krais (Dresden), H. Mark (Ludwigshafen), M. Mathieu (Paris),

No. 3284, Vol. 130] 
O. Roehrich (Paris), S. E. Sheppard (Rochester, N.Y.), H. de Witt Smith (New York), H. Staudinger (Freiburg), and J. J. Trillat (Paris).

During the years which have intervened between the two discussions, textile fibres and related substances have been studied by a wide variety of methods, and whereas in 1924 the properties of fibres could be explained only in terms of mechanical analogies, a much closer molecular interpretation of fibre structure has now become possible. It is generally recognised that fibres are constructed from long-chain molecules in which a definite unit is regularly repeated. In the case of cellulose fibres, the macromolecule consists of a chain of glucopyranose units linked through positions 1 and 4, while the corresponding units in the case of protein fibres are -CO-CHR-NHgroups, the constituent $\alpha$-amino acids being linked in this way to form a long peptide chain possessing side chains which vary in character according to the nature of the protein.

The real existence of such long-chain molecules has, in the case of cellulose, been demonstrated by Haworth using an ingenious application of the methylation technique. If the long molecules are not looped, hydrolysis of methylated cellulose must yield, in addition to trimethyl glucose, a small amount of tetramethyl glucose from the terminal glucose units. The relative proportions of the two compounds gives a measure of the length of the chain and its molecular weight. In the case of cotton cellulose the mean molecular weight was found to lie between 15,000 and 30,000 . It is satisfactory to note that Stamm, using Svedberg's ultracentrifugal technique, obtained a value of 40,000 , but Haworth's determination acquires exceptional significance because the molecular weight can be referred definitely to a single cellulose chain. By means of the ultracentrifuge, Svedberg has also determined the molecular weight of the monodisperse, soluble proteins and obtained values which were $1,2,3$ or 6 times 34,500. Similarly, in the case of derivatives such as cellulose acetate, the beautiful technique used by Büchner in measuring osmotic pressure has given values of the order of 35,000 for the mean molecular weight. Herzog pointed out, however, that the cellulose acetate used was probably not homogeneous and in a case which he had examined, the crude product gave fractions varying in molecular weight from 20,000 to 140,000 .

The point is important because Staudinger, from viscosity measurements with cellulose solutions, concluded that the molecular weight of cellulose was of the order of 120,000 . The validity of his viscosity law for compounds of high molecular weight was the subject of detailed discussion, a point of difficulty being the insistence that the molecules must be regarded as long rigid rods. Evidence for their flexibility was adduced by Adam from the properties of monomolecular films of long-chain compounds on a water surface, and it was further indicated by Sidgwick and Rideal that flexibility of the chains need not invalidate the viscosity law. While some difference of opinion still exists as to the precise magnitude of the molecular weight of the long-chain molecules of animal and vegetable fibres, it is satisfactory that all methods agree in giving a molecular weight of the order of 30,000 . That such widely different substances as cellulose and the proteins should have molecular weights of the same order of magnitude seems to suggest the existence of a common determining mechanism.

As regards the structure of the fibres composed of such molecules of high molecular weight, there has been a certain difference of opinion. On one hand, Mark has suggested that the molecules are arranged in bundles to form discrete micelles which are the secondary units of fibre construction. Neale and others see no necessity to postulate anything other than long-chain molecules which crystallise with varying degrees of perfection in the same fibre. Actually, there appears to be no essential difference between the two views, and a possible mode of reconciliation is to be found, as Astbury indicated, in Zwicky's recognition of a mosaic or secondary structure in the more familiar crystals. In the case of animal fibres at least, the real existence of micelles, less permeable to water than the fibre as a whole, has been abundantly demonstrated by swelling experiments which have been developed to give a measure of micellar thickness in good agreement with that derived from $\mathrm{X}$-ray and other evidence. With reagents other than water, the micelle structure may be dispersed, as in the case of wool fibres in acid solution, but removal of acid results in its reappearance.

The swelling of fibres, as suggested by Katz, may therefore be intramicellar, intermicellar or permutoid. In the case of wool, rigidity experiments and X-ray studies have clearly indicated that swelling occurs both by intra- and intermicellar water adsorption, and it was argued from the hysteresis phenomena in Marsh's determinations of the influence of adsorbed water on the electrical conductivity of wool, that intra- and inter-micellar water must function very differently in conductivity measurements. A possible method of discriminating between the two was suggested, based on the fact that the first five per cent of water adsorbed by wool is intramicellar. Similar considerations apply to cellulose, and Miles and Mathieu agree in concluding that nitration of cellulose does not proceed on an impervious micelle, but that it is penetrated by acid and nitrates throughout its whole structure simultaneously.

As regards the existence of micelles in solutions of cellulose and its derivatives, Adam showed that the ethers spread completely on water and if micelles exist in the original solution, cohesion is insufficient to prevent the formation of a monomolecular film. The esters and nitrates, on the other hand, showed incomplete spreading, while cellulose in cuprammonium solution was precipi-

No. 3284, Vol. 130] 
tated and not spread on water. Thus no decision can yet be made as to whether or not the micelles of cellulose retain their existence in solution.

Cohesion within the micelles of the wool fibre was shown to depend partially on salt formation between the acid and basic side linkages of the long chain molecules, as well as cystine linkages which are far more resistant to chemical attack. By analogy with the proteins, Mark was led to hint that the subtle differences between native and treated cellulose might depend on similar cross-linkages between the long-chain molecules of native cellulose, such linkages being opened by subsequent treatment. His hypothesis must be regarded as an extension of the views of Neale, who discriminated between two methods of modifying the properties of cellulose-by reactions which alter the reactivity of the hydroxyl groups associated with the long molecules, and those which modify the properties of cellulose by fission of the glucose chains.

In the case of wool and related fibres, the side linkages which have been identified as salts of arginine and glutamic acid, play an important part in determining the configuration of the long peptide chains. These have been shown by Astbury to be coiled into a series of pseudo-hexagons, whereas the peptide chains of silk are normally in the extended form. Since the side chains of silk are mainly non-reactive, it is reasonable to refer the coiled character of the peptide chains in wool to the endeavour of the more reactive acid and basic side chains to realise a condition of minimum potential energy by salt formation. Actually, a regular transition exists from silk with nonreactive side chains, through wool with salt. forming linkages, to feather which, according to Astbury, consists of long peptide chains bridged across by true peptide linkages. The importance of such side chains in determining the physical and chemical properties of proteins has now been fully recognised. For example, Miss Lloyd emphasised the part played by their length and reactivity in determining the extent of protein hydration and swelling. Similarly the salt linkages of wool are of fundamental importance in dyeing processes, and if Elöd's exhaustive application of the Donnan theory of membrane equilibria to the dyeing of wool with acid dyes is combined with the recognition of salt linkages, a precise interpretation of the mechanism of dyeing is possible. There can therefore be no doubt that the ingenious technique developed by Hughes for the study of protein films on water will prove invaluable as a simple and direct method of determining the properties of the fundamental long-chain protein molecule and its asseciated side chains.

\section{J. B. Speakman.}

\section{News and Views}

\section{The Wren Tercentenary Celebrations}

Sir Christopher Wren was born at East Knoyle, Wiltshire, on Oct. 20, 1632; and to mark the three hundredth anniversary of his birth a special service will be held in St. Paul's Cathedral on Oct. 20 at 4 P.M., and will be attended by the Lord Mayor and Sheriffs in state, and by representatives of the Royal Society, the Royal Academy, the Royal Institute of British Architects, the London Society, the Wren Society and other bodies. The service will be broadcast. The Dean and Chapter are also arranging an exhibition of portraits, models, documents, relics, etc., in the Trophy Room in the Cathedral which will be opened by Sir F. G. Hopkins on Oct. 10, and will be open to the public from Oct. 16 until Nov, 12 at 11 A.M. to 4 P.M. Though it was the rebuilding of the City of London after the Great Fire of 1666, which gave Wren a unique opportunity of displaying his genius as an architect, he had even before then designed the Pembroke College Chapel, Cambridge, and the Sheldonian Theatre, Oxford. His plans for rebuilding the City of London with a series of streets crossing each other at right angles, it is true were not adopted, but he was responsible not only for the design of St. Paul's Cathedral but also for the plans of some fifty churches, besides the Royal Exchange, the Custom House, Chelsea Hospital, Hampton Court, Greenwich Observatory and Buckingham Palace. The first stone of St. Paul's was laid on June 21, 1675 , and the last stone set in 1710 , thirteen years before Wren's death, which occurred on Feb. 25, 1723.
Wren's long life covered a part of the reign of Charles I, the period of the Commonwealth, the reigns of Charles II, James II, William and Mary, Anne, and the first nine years of the reign of George I. With the great social and political movements of the time he had little to do, but he will always be remembered as a distinguished man of science and England's greatest architect. From the days he was taught by Busby at Westminster School and came under the influence of Wilkins at Wadham College, Oxford, he gave evidence that he possessed unusual powers of mind, and at Oxford he quickly took a place among the devotees of science through whose efforts the Royal Society was founded. Like most of his contemporaries he made experiments in many branches of physics, and was particularly noted for his mechanical skill. At the age of twenty. five years he was appointed to succeed Rooke in the chair of astronomy at Gresham College, London, and four years later he succeeded Seth Ward as Savilian professor of astronomy at Oxford. This post he still held when he began his great career as an architect. The Royal Society was indebted to him in many ways. It was he who drew up the preamble to the charter of incorporation granted by Charles II in 1662; in an address in 1664 he urged the members not to flag in their efforts for it should be the aim of the Society to "plant Crabstocks for posterity to graft on", and when deeply engrossed with plans for a dozen churches he yet found time to serve as president. Many tributes to his genius

No. 3284, Vol. 130] 